\title{
The Accidental Business Historian
}

\author{
WILLIAM J. HAUSMAN
}

I want to begin with an apology to Anne Tyler, whose title I have so blatantly misappropriated. The idea of the "accidental business historian" has appealed to me for a long time, and I thought maybe Tyler's book also could provide a pithy lesson. ${ }^{1}$ Although a few of Macon Leary's character traits did strike a little close to home-there was a time, early in my career, that I would have considered multitasking by doing my laundry under foot while taking a shower-Macon's story is different from mine, except for the fact that we discovered our careers by accident.

But more about that shortly. Over the past few weeks I have enjoyed reading or rereading every presidential address given at the Business History Conference (BHC) since 1975, when the organization began publishing them regularly. ${ }^{2}$ They tend to be quite serious, and most of them stand very well the test of time.

In his 1975 address, Herman Krooss commented on the genre: "Presidential addresses that I have heard and observed come in four guises: What the discipline has done to me; What I have done to

(c) The Author 2007. Published by Oxford University Press on behalf of the Business History Conference. All rights reserved. For permissions, please e-mail: journals.permissions@oxfordjournals.org.

doi:10.1093/es/khm083

Advance Access publication November 20, 2007

WILLIAM J. HAUSMAN is Chancellor Professor of Economics at the College of William \& Mary. Contact information: Department of Economics, P.O. Box 8795, College of William \& Mary, Williamsburg, Virginia, 23187-8795, USA. E-mail:wjhaus@wm.edu.

I thank Colleen Kennedy, Pat Denault, Mira Wilkins, Sarah Stafford, Rob Hicks, Mike Blum, and Ron Rapoport for valuable assistance with my presentation and this essay.

1. Anne Tyler, The Accidental Tourist (New York, 1985)

2. For the years 1975-99 these can be found on the BHC web page. URL: http://www.thebhc.org/publications/BEHprint/presaddbeh.html (accessed 12 June 2007). From 2000 on, they usually have been published in the December issue of Enterprise \& Society. There was no presidential address published in 2003 and a symposium based on JoAnne Yates' address was published in the September 2006 issue of Enterprise \& Society. 
the discipline; The state of the discipline; And what you can do for the discipline. In other words, recollections, research, appraisal, and tasks."3 For the many years I was Secretary-Treasurer of this organization, I insisted that the Presidential address include at least some recollections, on the order of "how did you get into this field; who were your mentors?" I was not always obeyed, but I do intend to heed my own prior advice. Also, almost every BHC President has used the address to at least mention his or her own work, and I will be no exception. I have just completed-with Mira Wilkins, Peter Hertner, and others-what I think is a very exciting project, which I will turn to at the end of the address.

However, there are two things I am not inclined to do. First, I am not inclined to appraise the state of the field, since I have already written about this. ${ }^{4}$ Second, I most definitely am not inclined to suggest future directions for the field. You may think this is an irresponsible position for a President of the organization, but I think business history is very healthy precisely because it has been open to so many approaches and points of view. I trust that it will continue to be so, and that Enterprise $\&$ Society will reflect this. In my view, it would be a mistake to overly restrict the definition of business history. The BHC recently conducted a web survey, and it was very interesting to me that of the nearly 200 BHC members who responded, only 60 or 30 percent, indicated that the BHC was their primary professional organization. The health of the organization depends on our interdisciplinarity. I consider myself a business historian, but also an economic historian, a public policy historian, and a bit of a historian of technology.

So, let me get back to the title of this address, the accidental business historian. The point is that I don't think anybody grows up wanting to be a business historian. It happens by accident. Even Alfred D. Chandler, Jr. noted in his 1978 Presidential address, "All through my education - at local schools, then at Exeter and Harvard, I thoroughly enjoyed learning about the past. I loved history, but it never occurred to me that a historian might profitably study business.,"5

I also think a lot of young people have an inherent interest in commerce, industry, markets, and money, but that precious few grow

3. Herman E. Krooss, "Some Random Thoughts on Business and Government," Business and Economic History, second series, 4 (1975): 1.

4. William J. Hausman, "Business History in the United States at the End of the Twentieth Century," in Franco Amatori and Geoffrey Jones, eds., Business History Around the World (Cambridge, U.K., 2003), 81-110.

5. Alfred D. Chandler, Jr., "Business History-A Personal Experience,” Business and Economic History, second series, 7 (1978): 1. 
up wanting to be economists. I suspect a lot of them want to go into business. I grew up wanting to be a teacher, mainly because I liked school. By the time I was in college, I thought I wanted to be an accountant, a lawyer, or a college teacher. When I had to pick a major, I chose economics because I had a very low-key but inspirational instructor, because it seemed to be the more "academic" of the disciplines, and because my accounting professor was a stickler who publicly berated students for not wearing socks to class, which seemed inconsistent with the political and cultural tenor of the times (the late 1960s). Thus, I stumbled into economics, which at least I passably enjoyed. The next critical juncture, law versus economics, came in the final semester of college. I had applied to at least half a dozen law schools and been accepted at most. I had applied to one graduate school in economics, the University of Illinois, and I think I applied there only because it had a wacky nondissertation doctoral degree on the books. Although I did not know it when I applied, this degree had already been killed. Quite to my surprise, and for what reason I will never know, the University of Illinois offered me a full first-year scholarship — a free ride. I had amassed, what seemed at the time, to be a huge debt to attend William \& Mary, and was facing three more years of borrowing to attend law school. On the other hand, not only would I not have to pay tuition, but the University of Illinois was going to pay me to go to school-unbelievable. The temptation was just too much, and so, off I went.

I arrived in Champaign/Urbana in the fall of 1971, a remedial Ph.D. student on fellowship. I had neglected my math preparation and had to take an undergraduate course in calculus and a "baby" microeconomics course geared to non-Ph.D. students. ${ }^{6}$ I was miserable and almost quit, but did not find the time to do so. I thought I would specialize in urban economics, since I had had some excellent undergraduate classes in that field, including the only good history course I took-but that did not work out. I was not sure what I was going to do. Then, in my second year I took Donald Kemmerer's class in US economic history. ${ }^{7}$ Kemmerer, of course, was one of the founders of the BHC, although I did not know that at the time. It was a strange class, with a peculiar emphasis on skimming a large amount of literature, but I was intrigued. I was intrigued enough to enroll the

6. With that preparation, there is no way I would be accepted into a respectable Ph.D. program in economics today, and I think that is unfortunate. I almost certainly would have become a lawyer.

7. Economics graduate students at the time were required to take one economic history course, something rare today. 
next semester in a European Economic History course, taught by a young professor with a reputation for cynicism (which, in truth, was a wicked and highly developed sense of humor). Larry Neal, even though he was a full professor, had not yet supervised a doctoral thesis, but I was not thinking about writing a dissertation in economic history. Of course, taking this class turned out to be the best thing, professionally, that could have happened to me. Larry gave me a huge push down the path that has led to this address, opening many doors along the way. I became Larry's first doctoral student—-the first among many - and I have been grateful ever since.

My dissertation had its origins in one of the papers for Larry's European Economic History class. He suggested that I take a look at the eighteenth-century British pamphlet literature contained in the marvelous Jacob Hollander collection in the University Library. What I came across was a series of pamphlets dealing with the price of coal in mid-eighteenth-century London, including attempts on the part of the city of London to impose a price ceiling on coal. This was shortly after the first OPEC (Organization of the Petroleum Exporting Countries) embargo in October 1973, and the parallels intrigued me. An early energy crisis! Was there anything to be learned there?

London, from at least the seventeenth to the mid-nineteenth century, was almost totally dependent on sea-coal for its expanding energy needs. Coal was mined in the northeastern counties of Northumberland and Durham, where the mine-owners periodically attempted to form cartels, hence the analogy to OPEC. Coal was sent via primitive wagonways to the staiths on the Rivers Tyne and Wear, where it was loaded into ships, a highly competitive sector of the industry, and sent to London. There the coal was sold to brokers and merchants in the London pool, unloaded, and then distributed to various large purchasers and retailers. There were taxes at both ends of the trade, and for that, thank goodness, because it meant that records were kept.

This supply chain was complex, comprised of sectors with differing organizational structures, and was highly controversial, and thus constantly under the scrutiny of city officials and Parliament. There were a lot of contemporary words written about the London coal trade, both in pamphlets and in Parliamentary papers, as well as some excellent, and not so excellent, historical treatments. I decided to see if I could make a dissertation of it and Larry agreed.

In addition to the considerable resources at the University of Illinois, Larry made me aware of other sources of potential information and support. At the time, Harvard University's Kress Library of Business and Economics had a program in which it brought in about 
a dozen scholars ranging in age from graduate students to emeriti faculty to use the resources of the library for up to 4 weeks in the summer. In what turned out to be the last year of the program, I was able to spend time in the Kress library, examining yet more literature, and receiving the incomparable advice of Fritz Redlich and others. ${ }^{8}$

Larry was adamant about one thing; if I was going to write a dissertation on British economic history, I would have to go to Britain. So, off I went to London, first on a research trip and later, as I was finishing up, as a research student at the London School of Economics, where Arthur John was my advisor. When I first went to London I had a strong sense of where I should go- to the Guildhall Library, which houses the records of the City of London. What I found mostly were more pamphlets. I needed something more; I wanted evidence, some data I could use. Decent data on coal prices were available thanks to the work of William Beveridge and J.E.T. Rogers, but quantity figures were spotty for the eighteenth century. ${ }^{9}$ I cannot remember precisely how or why, but somebody in the library directed me to the Corporation of London Record Office, around the back of the building, up a flight of stairs, to a dingy, cramped reading room, to see what they might have. There I hit academic paydirt. As I have mentioned, coal was taxed at several points in the supply chain, by several authorities. One of these was the Corporation of London, which collected 10d. per chaldron on coal imported into London. ${ }^{10}$ This was known as the Orphans' Duty, although by the early eighteenth century it had ceased to have anything to do with orphans and had morphed into a general fund for the City of London, mostly to support public works projects. The Collector's Returns of the Orphans' Duty listed every ship that unloaded coal in London from 1698 to 1770, including ship master, ship name, and amount unloaded. ${ }^{11}$ Given the technological limits of the time (meaning we had only room-sized mainframe computers that did not travel well), all I managed to record were the monthly totals of coal unloaded, number of ships, and tax collected. When back at Illinois, this was translated into machine-readable form (and

8. The Kress collection is now part of the Historical Collections Department of Baker Library at Harvard. URL: http://lib.harvard.edu/archives/0010.html (accessed 12 June 2007).

9. William Beveridge, Prices and Wages in England from the Twelfth to the Nineteenth Century, Vol. 1 (London, 1939), and James E. Thorold Rogers, A History of Agriculture and Prices in England, 7 vols. (Oxford, U.K., 1902).

10. The London chaldron was a unit of volume fixed by statute. By the eighteenth century it was approximately equivalent to $11 / 3$ tons.

11. Corporation of London Record Office, Collector's Returns of the Orphans' Duty, 1694-1775, 25 vols., Ms. 429 b-c. 
by that I mean typed on an IBM punch-card machine). I then devised what I believe was an appropriate supply-and-demand model and estimated it. My basic conclusions were as follows: (1) The London coal market in the eighteenth century was a well-functioning market, with upward sloping supply curves and downward sloping demand curves; (2) Legislative acts (price ceilings and anticombination acts) were ineffective in lowering the price of coal; (3) A mine owners' cartel existed periodically but had no effect on the price of coal in London (because, I believe, there was fringe competition from newly opened pits, which caused restraint on the part of existing mine owners); (4) The tax on coal was substantial and had a larger impact on price by far than any other public policy; (5) Colliers were earning a normal return on capital invested. ${ }^{12}$ In later work, I extended the time period and came to the same basic conclusions. ${ }^{13}$ At the time, I thought of this research as pure economic history, but I now view it as residing at the intersection of economic, business, and policy history, and my first professional publication, based on an appendix to the dissertation, was published in the Business History Review. ${ }^{14}$ That is how I became an accidental business historian, which explains my involvement with the BHC, whose recent history I would like to turn to. I have been involved with the BHC, in one capacity or another, as a member, Trustee, Secretary-Treasurer, and/or editor of all its journals, for 32 years, or over 60 percent of its existence, and 55 percent of mine.

It was Larry Neal again, along with Don Kemmerer and Paul Uselding, who introduced me to the BHC while I was still in graduate school at Illinois, as part of the professional training we were getting. It was more unusual then for graduate students to attend professional conferences than it is now. Today, graduate student participation is an integral part of the annual meeting, and I think encouraging that participation has been one of our greatest recent accomplishments. The 1975 conference, the first I attended, was at the same site,

12. See William J. Hausman, Public Policy and the Supply of Coal to London, 1700-1770 (Ph. D. diss., University of Illinois, 1976) and William J. Hausman, "A Model of the London Coal Trade in the Eighteenth Century," Quarterly Journal of Economics 94 (Feb. 1980): 1-14.

13. William J. Hausman, "Market Power in the London Coal Trade: The Limitation of the Vend, 1770-1845," Explorations in Economic History 21 (Oct. 1984): 383-405. For a recent survey article on cartels, see our program co-chair's article, Margaret C. Levenstein and Valerie Y. Suslow, "What Determines Cartel Success?", Journal of Economic Literature 44 (March 2006): 43-95.

14. William J. Hausman, "Size and Profitability of English Colliers in the Eighteenth Century,” Business History Review 51 (Winter 1977): 460-73 
Northwestern University, as the first meeting, in 1954, of what was to become the BHC. ${ }^{15}$ The organization was known originally as the Midwestern Conference on Business History, because it was begun by people teaching at mid-western universities; its meetings did not venture out of the mid-western heartland until into its second decade of existence (and then at first, only to Texas, twice). ${ }^{16}$ Thereafter, the organization broadened its scope and dropped the Midwestern from its title, becoming just the BHC, a name, by the way, that still confuses some since it does not contain the words "association," "society," or "organization."

The 1975 meeting also coincided with the inception of the regular publication of Business and Economic History (BEH). Prior to this time, proceedings had been published irregularly and in a variety of formats. Thanks to Paul Uselding, and with the support of the Bureau of Business Research at the University of Illinois, regular publication became possible. Paul edited $B E H$ for 6 years, turning over the editorial duties to Jeremy Atack in 1981. Jeremy performed the dual duties of Secretary-Treasurer of the BHC (having taken over this duty from Fred Bateman) and editor of $B E H$ for 7 years. I became Secretary-Treasurer of the BHC and editor of $B E H$ in 1987, thus continuing what was known by some, affectionately I believe, as the Illinois Mafia.

When I became Secretary-Treasurer and editor in 1987, 20 years ago, the organization was very different than what it is today. We had fewer than 200 members. The financial assets of the organization consisted solely of a single checkbook with a balance of about $\$ 5,000$. Today, we have assets and endowments of nearly $\$ 200,000$. There was little structure to the organization. We were not even an officially recognized organization, which had potential financial implications. One of the first things I did was to work on getting the BHC tax-exempt status, which necessitated incorporating, not as easy as I thought it would be, but which I finally managed to do with the help of a William \& Mary law student, and in spite of an IRS agent who had absolutely no clue about what an academic organization was or did.

Back then, the President-elect was solely responsible for organizing the program of the annual meeting. There was only one committee,

15. Papers were given at this 1975 conference by our host this year, Gary Previts, and our President-elect, Mark Rose. See the table of contents on the BHC web site. URL: http://www.thebhc.org/publications/BEHprint/toc41975.html (accessed 12 June 2007).

16. A list of past meeting venues can be found on the BHC web site. URL: http://www.thebhc.org/annmeet/annmeets.html (accessed 12 June 2007). 
comprised of the President, President-Elect, and Past-President, which essentially served as an executive committee as well as the nominating committee. That was it. However, much like today, final responsibility for all decisions rested with an elected Board of Trustees. Today, we have a rich governance structure, with a plethora of committees, absolutely necessary for the running of a much more complex and active organization. ${ }^{17}$

One of the changes I have seen and am most pleased about is the growing international scope of the organization. We have now met four times outside the United States, twice in Canada, once jointly with the UK-based Association of Business Historians in Glasgow, Scotland, and most recently with the European Business History Association (EBHA) in Le Creusot, France. We will meet again with the EBHA in Milan, Italy in 2009. In addition, the EBHA met jointly with us several years ago in Lowell, Massachusetts. I hope this international cross-fertilization will continue and perhaps even expand in scope to encompass other areas of the world.

I also have witnessed, and am proud to have played a role in, the tremendous changes in the publishing program of the BHC. Here is something that was not entirely accidental, even if it was not completely planned either. The evolution of our publishing program seems to me to have formed a natural progression, determined in part by cost, technology, and demand. The fact that the popularity of business history has grown over the past 20 years has helped immensely. Responding to expanding demand can make even blockheads look good. But I think the BHC recognized the market and tapped it. What I think we did not fully anticipate, and hence might be called accidental, was the impact of digital access.

Here's the story in a nutshell. When I became editor of $B E H$, it was an annual proceedings volume. Most of the papers given at the conference were published; it was expected of authors. We produced the journal on a computer in the William \& Mary economics department office and created camera-ready copy, which was sent to an outside printing company. ${ }^{18}$ When I first started, most of the papers were mailed to me on 51/4 inch diskettes, but about a third of the papers were sent only as hard copy, so they had to be retyped, an annoying deadweight

17. The current committee structure can be found on the BHC web site. URL: http://www.thebhc.org/governance/people.html (accessed 12 June 2007).

18. A succession of Deans of Arts and Sciences has supported my involvement with the BHC during all the years of editing BEH, Enterprise $\&$ Society, and now BEH On-Line. The BHC owes the College of William \& Mary a considerable debt of gratitude. 
loss. The printer distributed copies to members and we sent out the institutional subscriptions from the department office. Members received a copy for their $\$ 15$ dues, and we charged the small number of libraries that subscribed (about 100 of them) \$15. It was like running a very small business. I cannot say I enjoyed the production part of this. From the first issue onward, I quite selfishly wondered if I could get a publisher interested in $B E H$ and get it off my desk, and whether this would be financially feasible for the organization. I informally contacted a few publishers, and the answer was that nobody was going to pick up an annual conference proceedings. We never got to the economic feasibility stage. The next best thing, it seemed to me, was to do something to enhance the prestige of the journal. This is where the idea for the second, what I always called quasi-refereed, issue of the journal came from. This would never have been possible if our annual meetings had not grown in popularity and if our various hosts had not became adept at garnering financial support. It became an informal rule, or at least a stated goal, that the annual conference had to generate enough surplus revenue to publish the second volume of $B E H$. This was about $\$ 4,000-\$ 5,000$ at the time. To be considered for inclusion in the second issue, authors had to submit their papers a few weeks before the meeting. I then selected a small committee, usually including the President, to "referee" the papers submitted. Four or five were then selected for the second issue of the volume and authors were given comments and were allowed time to revise their papers. In the meantime, in order to stimulate interest in business history, the Newcomen Society of the United States had agreed to fund a prize of $\$ 1,000$ to be awarded to what the committee of referees determined to be the best conference paper. The first quasi-refereed issue of $B E H$ was published in 1993. ${ }^{19}$ Steve Usselman, currently President of the Society for the History of Technology, was awarded the Newcomen Prize that year. This second issue, of course, almost doubled the amount of production work for me and the economics department secretary. I wondered if this was going in the right direction.

I think this system worked well from 1993 to 1996, and we published some excellent papers. Then in 1997, $B E H$ was fortunate to be able to publish the proceedings of a conference on "The Future of Business History” organized by Roger Horowitz and Philip Scranton, and held at the Hagley Museum and Library in Wilmington,

19. Business and Economic History 22 (Winter 1993). URL: http://www.thebhc. org/publications/BEHprint/toc22b1993.html (accessed 12 June 2007). 
Delaware. ${ }^{20}$ This precluded publication of a quasi-refereed issue that year, since the normal issue already was quite large. And in 1998 there were so many papers given at the meeting that it was decided not to try to make the second issue quasi-refereed but just to publish the regular papers in two issues.

By this time, it was clear that business history was on a roll. The BHC was thriving. The field was wide open. There were other fine business history journals, including Business History Review, published at the Harvard Business School, and the British journal, Business History. They each seemed to have a comfortable niche, but the field was expanding. It seemed like an opportune time to try again to find a publisher for a wide-ranging business history journal, one especially open to many viewpoints, including the cultural approach. The BHC was maturing and it seemed that it should have its own journal. However, it remained clear that no house was going to publish conference proceedings. Nevertheless, we again approached publishers with informal contacts. This time we got enough of a nibble from Cambridge University Press that Pat Denault and I filled out a standard form, much like a book proposal form. Without that nibble, we may never have proceeded. Larry Neal, who was President-Elect at the time, enters the picture again here. Larry had just published a book with Oxford University Press (OUP) and suggested that since we had already addressed the crucial questions, we might as well send the proposal to OUP also. Phil Scranton and Roger Horowitz (by that time slated to become Secretary-Treasurer, and destined to edit the last hard-copy issue of $B E H$ ) and their colleagues at the Hagley suggested a name change for the new journal, from the rather mundane title we had come up with, to Enterprise \& Society: The International Journal of Business History, which reflected the wide scope intended for the journal. This idea was readily accepted.

The rest is history. Cambridge expressed no further interest. OUP sent the proposal out to referees, some of whom probably are in this room, and it was favorably received. They were ready to proceed. All that was needed was the approval of the Trustees. What followed was a more vigorous discussion of the pros and cons of pursuing this endeavor than I had anticipated. The fate of the proceedings volume was uncertain. A number of scholars, both younger (one of whom informed me that he had gotten his first job because of an article in $B E H$ ) and older, had a fondness for it that I had not

20. Business and Economic History 26 (Fall 1997). URL: http://www.thebhc. org/publications/BEHprint/toc26a1997.html (accessed 12 June 2007). 
fully appreciated. It was hoped that maybe OUP would publish and distribute the proceedings as a subsidiary volume, but this was not part of the agreement. In addition, the size of the annual meeting was growing such that a full proceedings volume would have been impossibly large. Several people suggested that the proceedings could be published online. This is eventually what happened, after a 3-year hiatus, beginning in $2003 .^{21}$

Probably the biggest concern of the Trustees was the financial implication for the BHC of our new publishing ventures. We anticipated that the journal would lose money in its first 4 years, break even in the fifth, and then start to show a surplus. Losses would be accumulated and then paid down out of future profits; after the cumulative losses were eliminated, the BHC and OUP would split any surplus evenly. But what if it were a complete bust and OUP or the BHC wanted to pull out? The BHC could be wiped out financially. But, when asked, OUP (quickly, and wisely in retrospect) indemnified the BHC against this event. They were willing to accept the biggest financial risk. The trustees then agreed to the proposal, and I was appointed editor. I served my 4-year term and it was incredibly rewarding if incredibly hard work. The core editorial team of Steven Tolliday, David Sicilia, and Sally Clarke, with Phil Scranton handling the book reviews, was simply superb. Without them Enterprise \& Society (E\&S) would not have been such a success. Ken Lipartito and his editorial team carried on, and the success has been magnified. I have every confidence that Phil Scranton will continue the tradition.

And what a success E\&S has been! In its first year, $E \mathscr{E} S$ won the best new journal in Business, Social Sciences, and the Humanities from the scholarly and professional publishing division of the Association of American Publishers. As was expected, E\&S ran deficits in its early years, the cumulative deficit reaching a peak (trough, really) of $\$ 108,000$ in 2003. But it went from running a loss to generating a surplus in 2004, a year earlier than expected. And the surplus has continued to grow, so that the cumulative deficit has been paid down and at the end of 2006 stood at a mere $\$ 7,000$. Unless there is a major setback, the BHC will be earning money on its journal in future years. $E \& S$ has been successful for several reasons, not the least of which is the high quality of the articles and reviews. In addition, membership numbers and institutional subscriptions have remained steady. Finally, subscriptions through consortia and

21. BEH On-Line can be found on the BHC web site. URL: http://www.thebhc. org/publications/BEHonline/beh.html (accessed 12 June 2007). 
electronic downloads through entities such as Project Muse have substantially contributed to an improved the bottom line.

The impact of electronic access has been astonishing in terms of both enhancing revenue and reaching people. In the calendar year 2006, there were over 15,600 articles or reviews downloaded (mostly paid for through library or consortia subscriptions) from the cumulative issues (2000-06) of E\&S. Over 70,000 times last year, people visited the Journal's homepage or downloaded abstracts or tables of contents. ${ }^{22}$ That represents a substantial amount of interest in business history. I think the BHC did the right thing when it launched Enterprise \& Society.

Now, as promised earlier and finally, I would like to put in a plug for my recent research project with Mira Wilkins, Peter Hertner, and others. ${ }^{23}$ This effort represents, for me, the closest thing to what you might consider pure business history. The project began many years ago, but its fruit, a book manuscript, just a few weeks ago was entered into production at Cambridge University Press. ${ }^{24}$ The book is an attempt to understand how multinational enterprise and international finance have influenced the course of electrification around the globe. We focus on foreign direct investment (FDI) in electric utilities over the course of the history of the industry. We describe the crucial early engagement of FDI, its expansion around the globe in the first three decades of the twentieth century, its eventual contraction through domestic buy-out, confiscation, or withdrawal, and its recent, vigorous revival. Our book describes multinational enterprise-moving capital, ownership and control, management, technology, processes, procedures, and know-how across borders-in its various and often nonconventional forms. We believe this story adds substantially to our understanding of the ways in which multinational enterprises developed their strategies over time as they diffused electrification around the globe. We believe that one of the real contributions of our global electrification book is its integrative nature; we are not simply comparing one national experience with another but showing how various national experiences are linked in a complex and important manner. We hope you will enjoy it.

22. "Enterprise \& Society, Publisher's Report for the Business History Conference," prepared by Journals Division, Oxford University Press, May 2007.

23. Other contributors to the project included Dominique Barjot, Jonathan Coopersmith, Ken Jackson, Pierre Lanthier, Viv Nelles, John Neufeld, Harm Schröter, and Luciano Segreto.

24. William J. Hausman, Peter Hertner, and Mira Wilkins, Global Electrification: Multinational Enterprise and International Finance in the History of Light and Power, 1878-2007 (New York and Cambridge, U.K., forthcoming). 